\title{
INTEGRASI NILAI MULTIKULTURAL DALAM PEMBELAJARAN PENDIDIKAN AGAMA ISLAM DI SEKOLAH DASAR
}

\author{
Lusia Mumtahanah \\ Universitas Islam Negeri Sunan Ampel Surabaya \\ E-mail: lusiariouz2@gmail.com
}

\section{Naskah Diterima: 15-11-2019 Direvisi: 24-12-2019 Disetujui: 15-01-2020}

\begin{abstract}
The integration of multicultural values is a process to acquire the knowledge, the development of attitudes and behavior in order to live mutual respect, tolerance, full of peace, mutual aid, and nonviolence. Islamic religious education is education that is focused more on the improvement of mental attitude manifested in deeds, both for the purposes of self and others, both theoretical and practical. This study three research focus, firstly any form of multicultural values in the learning of Islamic religious education at SDN 1 Balun Turi Lamongan?, Second, How is the implementation of multicultural values in the learning of Islamic religious education?? Third, How to enabling and inbibiting factors integration of value - the value of multicultural learning PAI at SDN 1 balun Turi Lamongan?. The research is a qualitative descriptive approach. Collecting data through interviews, observation and documentation. The method is the data analysis data reduction, presentation of data, conclusion drawing/verification. The results of this study indicate that 1) Form of multicultural values which are applied in the process of integration in which PAI learning Inclusive V alue (Open), Human V alues (Humanist), the value of tolerance, the value of Please Help, the value of Justice (Democratic) and nuse values Equality and Fraternity (brotherhood), 2) the implementation of the integration of multicultural values in PAI learning done in the planning, implementation and evaluation of learning. 3) The supporting factors that exist as a unified educational curriculum, textbooks laden multicultural content and the enabling environment as well as religious. While the inbibiting factor is the lack of media diversity in the school environment, multicultural load content in the RPP is still less so is dominated environmental factors.
\end{abstract}

Keywords: Integration, Value Multicultural, PAI learning

\begin{abstract}
Abstrak
Integrasi nilai-nilai multikultural adalah proses untuk memperoleh pengetahuan, pengembangan sikap dan perilaku untuk hidup saling menghormati, toleransi, penuh kedamaian, saling membantu, dan tanpa kekerasan. Pendidikan agama Islam adalah pendidikan yang lebih fokus pada peningkatan sikap mental yang diwujudkan dalam perbuatan, baik untuk keperluan diri sendiri maupun orang lain, baik secara teoritis maupun praktis. Penelitian ini fokus pada tiga penelitian, pertama segala bentuk nilai multikultural dalam pembelajaran pendidikan agama Islam di SDN 1 Balun Turi Lamongan?, Kedua, Bagaimana penerapan nilai-nilai multikultural dalam pembelajaran pendidikan agama Islam?, Ketiga, Bagaimana cara mengaktifkan dan menghambat faktor integrasi nilai - nilai PAI pembelajaran multikultural di SDN 1 balun Turi Lamongan ?. Penelitian ini adalah pendekatan deskriptif kualitatif. Mengumpulkan data melalui wawancara, observasi dan dokumentasi. Metode analisis data adalah reduksi
\end{abstract}


data, penyajian data, penarikan kesimpulan / verifikasi. Hasil penelitian ini menunjukkan bahwa 1) Bentuk nilai multikultural yang diterapkan dalam proses integrasi di mana PAI belajar Nilai Inklusif (Terbuka), Nilai Manusia (Humanis), nilai toleransi, nilai Tolong Tolong, nilai Tolong, nilai Keadilan (Demokratis) dan nilai-nilai kesetaraan Kesetaraan dan Persaudaraan (persaudaraan), 2) implementasi integrasi nilai-nilai multikultural dalam pembelajaran PAI dilakukan dalam perencanaan, implementasi dan evaluasi pembelajaran. 3) Faktor-faktor pendukung yang ada sebagai kurikulum pendidikan terpadu, buku teks sarat konten multikultural dan lingkungan pendukung serta agama. Sementara faktor penghambatnya adalah kurangnya keragaman media di lingkungan sekolah, konten muatan multikultural di RPP masih kurang sehingga didominasi faktor lingkungan.

Kata Kunci: Integrasi, Nilai Multkultural, Pembelajaran PAI.

\section{PENDAHULUAN}

Indonesia juga menganut agama dan kepercayaan yang beragam seperti Islam, Katholik, Protestan, Hindu, Budha, Konghucu, serta berbagai macam kepercayaan. Keragaman ini akan melahirkan kebudayaan (culture) yang berbeda-beda sehingga bangsa ini termasuk salah satu negara multikultural terbesar di dunia ${ }^{1}$. Berangkat dari keragamaan kebudayaan itulah maka terbentuk sebuah motto Bhinneka Tunggal Ika yang artinya beragam namun menyatu dalam satu ikatan. Dengan kata lain pluralitas memperkaya kehidupan dan menjadi esensi kehidupan masyarakat ${ }^{2}$.Namun di sisi lain, hal tersebut juga rentan terhadap konflik sosial yang akan mengancam integrasi bangsa. Berbagai kasus dan peristiwa yang berbau SARA (suku, agama, ras, dan antar golongan) sering terjadi di negeri ini $^{3}$.

Dalam perkembangan zaman dewasa ini, pendidikan merupakan tonggak sentral untuk memperbaiki mutu manusia yang dituntut untuk selalu tanggap dengan setiap hal yang bersifat baru dan mutakhir. Tidak hanya pendidikan yang bersifat umum, pendidikan yang bersifat keagamaan juga dituntut agar selalu bisa berkembang dengan mengeksplorasi seoptimal mungkin setiap kajian yang ada di dalamnya. Diakhir dekade ini, pendidikan agama di sekolah banyak mendapatkan sorotan tidak baik. Pendidikan agama banyak menuai kritik. Kritik yang

${ }^{1}$ Muhammad Aji Nugroho, "Pendidikan Islam Berwawasan Multikultural; Sebuah Upaya Membangun Pemahaman Keberagamaan Inklusif Pada Umat Muslim," MUDARRIS A: Jurnal Kajian Pendidikan Islam 8, no. 1 (September 10, 2016): 31-60, https://doi.org/10.18326/mdr.v8i1.31-60; Puspo Nugroho, "Internalization of Tolerance Values in Islamic Education," Nadwa 12, no. 2 (January 7, 2019): 197-228, https://doi.org/10.21580/nw.2018.12.2.2397; Muhammad Anas Ma`arif, "Internalisasi Nilai Multikulutural Dalam Mengembangkan Sikap Toleransi ( Studi Di Di Pesantren Mahasiswa Universitas Islam Malang)," Naz̧hruna: Jurnal Pendidikan Islam 2, no. 1 (March 24, 2019), https://doi.org/10.31538/nzh.v2i1.179.

2 Mursyid Mursyid, "Internalisasi Nilai Keberagaman Agama Dan Paham Keislaman Di Pondok Pesantren: A Sociological Approaches," Jurnal Kependidikan Islam 5, no. 2 (August 1, 2015): 125-48; Said Aqil Husin Al Munawar, Hasan M. Noer, and Musyafaullah, Hukum Islam dan pluralitas sosial (Penamadani, 2004).

${ }^{3}$ Faisal Ismail, Dinamika kerukunan antarumat beragama: konflik, rekonsiliasi, dan harmoni, Cetakan pertama (Bandung: PT Remaja Rosdakarya, 2014). 
paling menonjol adalah bahwa dirasakan pendidikan agama kurang berdampak pada kehidupan yang lebih baik dari para siswa tersebut setelah mengalami proses pendidikan. Hal ini sependapat dengan Husniyatus S bahwa di era multikulturalisme dan pluralism, pendidikan agama sedang mendapat tantangan karena ketidakmampuannya dalam membebaskan peserta didik ke luar dari eksklusifitas beragama. Wacana kafir-iman, muslim-non muslim, surganeraka menjadi bahan di kelas selalu diindoktrinasi. ${ }^{4}$

Pelaksanaan integrasi nilai-nilai multikultural dalam pembelajaran pendidikan agama merupakan pendidikan yang memberikan peluang yang sama pada seluruh anak bangsa tanpa membedakan perlakuan karena perbedaan perbedaan etnik, budaya, dan agama serta menghendaki penghormatan dan penghargaan manusia setinggi-tingginya terhadap harkat dan martabat manusia dari manapun latar belakang budayanya ${ }^{5}$. Dalam penelitian ini peneliti membahas tentang PAI atau pendidikan agama Islam sebagai bagian yang integral dari pendidikan agama di Indonesia, PAI mempunyai peran yang tidak sedikit dalam menciptakan perilaku yang berwawasan multikultural bagi siswa ${ }^{6}$.

Pelaksanaan pendidikan multikultural sangatlah penting dan urgen untuk diterapkan di sekolah-sekolah ${ }^{7}$. Oleh karena itu diperlukan sebuah konsep baru yaitu tentang nilai-nilai multikultural yang terintegrasi dalam pembelajaran pendidikan agama Islam (PAI) di sekolah. Selain itu banyak muatan nilai yang terkandung dalam pendidikan Islam yang sejalan dengan nilai multikultural, seperti nilai andragogi, nilai perdamaian, nilai inklusivisme, nilai kearifan, nilai toleransi, nilai humanisme, nilai kebebasan dan nilai yang lainnya. Namun demikian juga diperlukan konsep yang jelas terkait dengan nilai-nilai multikultural yang terintegrasi dalam pembelajaran pendidikan agama Islam di sekolah untuk mewujudkan adanya pluralisme

${ }^{4}$ Husniyatus Salamah Zainiyati, "Pendidikan Multikultural: Upaya Membangun Keberagamaan Inklusif Di Sekolah,” Islamica: Jurnal Studi Keislaman 1, no. 02 (2007): 135-145.

5 Jihan Abdullah, "Pendidikan islam multikultural di pesantren (studi kasus pada pondok modern ittihadul ummah gontor poso)," Istiqra 2, no. 1 (June 30, 2014): 95-123, https://doi.org/10.24239/istq.v2i1.103.95-123; Ismail Ismail, "Nilai-Nilai Karakter Dalam Pendidikan Agama Islam Berbasis Multikultural," TADRIS: Jurnal Pendidikan Islam 8, no. 2 (2014): 215-234; Achmad Asrori, "Contemporary Religious Education Model on the Challenge of Indonesian Multiculturalism," JOURNAL OF INDONESLAN ISLAM 10, no. 2 (December 1, 2016): 261-84, https://doi.org/10.15642/JIIS.2016.10.2.261-284; James A. Banks, ed., The Routledge International Companion to Multicultural Education, Routledge International Handbook Series (New York ; London: Routledge, Taylor \& Francis Group, 2009).

${ }^{6}$ Hamlan Andi Baso Malla, "Pembelajaran Pendidikan Agama Islam Berbasis Multikultural Humanistik Dalam Membentuk Budaya Toleransi Peserta Didik Di SMA Negeri Model Madani Palu, Sulawesi Tengah," INFERENSI: Jurnal Penelitian Sosial Keagamaan 11, no. 1 (June 1, 2017): 163-86, https://doi.org/10.18326/infsl3.v11i1.163-186; Raihani, Pendidikan Islam Dalam Masyarakat Multikultural, Cet. 1 (Yogyakarta: Pustaka Pelajar, 2016).

7 Muhammad Anas Ma`arif, "Pendidikan Multikultural Sebagai Pembentukan Karakter Peserta Didik," Ta'lim: Jurnal Studi Pendidikan Islam 2, no. 2 (July 15, 2019): 136-52, https://doi.org/10.29062/ta'lim.v2i2.1413; Andika Aprilianto and Muhammad Arif, "Pendidikan Islam Dan Tantangan Multikultural: Tinjauan Filosofis," Nazhruna: Jurnal Pendidikan Islam 2, no. 2 (August 11, 2019): 279-89, https://doi.org/10.31538/nzh.v2i2.339. 
dan multikulturalisme yang ada di Indonesia. Terkait dengan apa yang telah dijelaskan di atas, penulis memilih SD Negeri 1 Balun Turi Lamongan sebagai objek penelitian dikarenakan ada indikasi bahwa sekolah ini telah melaksanakan integrasi nilai-nilai multikultural dengan baik dalam proses pembelajarannya, khususnya pembelajaran Pendidikan Agama Islam. Oleh karena itu penulis disini ingin meneliti lebih jauh serta menganalisis dan mendeskripsikan tentang pelaksanaan integrasi tersebut. Hal ini karena SD Negeri 1 Balun Turi Lamongan telah menjadi sekolah yang sedang menerapkan pengembangan nilai budaya dan karakter bangsa.

\section{METODE}

Pendekatan yang dilakukan dalam penelitian ini adalah pendekatan fenomenologi yaitu studi tentang penampakan sebuah objek, peristiwa, atau kondisi dalam persepsi individu. Pendekatan ini dilakukan dalam keadaan yang sebenarnya sehingga tidak ada batasan bagi peneliti untuk memaknai kejadian atau fenomena yang dikaji. Penelitian ini menggunakan jenis penelitian kualitatif yaitu suatu penelitian ilmiah yang bertujuan untuk memahami suatu fenomena dalam konteks sosial secara alamiah dengan mengedepankan proses interaksi komunikasi yang mendalam antara peneliti dengan fenomena yang diteliti ${ }^{9}$ Penelitian kualitatif bersifat deskriptif dengan melakukan penggambaran secara mendalam tentang situasi yang diteliti sehingga dalam jenis penelitian ini peneliti tidak berusaha untuk menguji hipotesis seperti halnya dalam penelitian kuantitatif. ${ }^{10}$

Kehadiran peneliti dalam penelitian ini adalah sebagai pengamat partisipan atau berperan serta, artinya dalam proses pengumpulan data peneliti mengadakan pengamatan dan mendengarkan secara cermat sampai pada yang sekecil-kecilnya ${ }^{11}$. Dalam penelitian ini, peneliti memilih SDN 1 Balun Turi Lamongan sebagai lokasi penelitian. (berdasar hasil observasi/pra research) antara lain yakni, merupakan salah satu sekolah yang menerapkan pendidikan multikultural, yang memiliki siswa siswi dengan latar belakang agama berbeda

8 Heddy Shri Ahimsa-Putra, "Fenomenologi Agama: Pendekatan Fenomenologi Untuk Memahami Agama," Walisongo: Jurnal Penelitian Sosial Keagamaan 20, no. 2 (December 15, 2012): 271-304, https://doi.org/10.21580/ws.20.2.200; Kuswarno Engkus, Metodelogi Penelitian Komunikasi, Fenomenologi, Konsepsi dan Pedoman (Bandung: Widya Padjadjaran, 2009); O. Hasbiansyah, "Pendekatan Fenomenologi: Pengantar Praktik Penelitian dalam Ilmu Sosial dan Komunikasi," MediaTor (Jurnal Komunikasi) 9, no. 1 (June 10, 2008): 16380, https://doi.org/10.29313/mediator.v9i1.1146.

9 Asep Sudarsyah, "Kerangka Analisis Data Fenomenologi (contoh Analisis Teks Sebuah Catatan Harian)," Jurnal Penelitian Pendidikan 13, no. 1 (August 23, 2016), http://ejournal.upi.edu/index.php/JER/article/view/3475; Stefanus Nindito, "Fenomenologi Alfred Schutz: Studi Tentang Konstruksi Makna Dan Realitas Dalam Ilmu Sosial," Jurnal Ilmu Komunikasi 2, no. 1 (2013).

10 Dr Drs I. Wayan Suwendra M.Pd S. Pd, Metodologi Penelitian Kualitatif dalam Ilmu Sosial, Pendidikan, Kebudayaan dan Keagamaan (Nilacakra, 2018); Muhammad Farid, Fenomenologi Dalam Penelitian Ilmu Sosial (Rawamangun, Jakarta: Kencana, 2018).

11 Arikunto Suharsimi, Prosedur Penelitian, Suatu Pendekatan Teori dan Praktek, 14th ed. (Jakarta: Rineka Cipta, 2010), 1. 
yakni Islam, Hindu dan Kristen dan terdapat 3 kurikulum didalamnya. Sehingga akan lebih menarik untuk mengetahui proses integrasi nilai-nilai multikultural dalam pembelajaran agama islam (PAI).

Data primer adalah data yang didapat langsung dari subyek penelitian dengan menggunakan alat pengukuran atau alat pengambilan data langsung pada subyek sebagai sumber informasi yang dicari ${ }^{12}$. Data primer bisa didapat melalui survei dan metode observasi. Dalam penelitian ini yang menjadi sumber data atau informan adalah: Kepala sekolah, Guru pendidikan agama Islam, Beberapa dewan guru SDN 1 Balun Turi Lamongan, Beberapa Siswa kelas IV dan V . Tehnik pengumpulan data melalui observasi langsung di lokasi penelitian, wawancara dengan informan dan dokumentasi. Tehnik analisis menggunakan: (1) Data Reduction (Reduksi Data) (2) Data Display (Penyajian Data)(3) Conclusion Drawing/verification.

\section{HASIL}

SDN 1 Balun Lamongan terletak di dusun Balun kecamatan Turi kabupaten Lamongan merupakan sekolah negeri dalam naungan pemerintah lamongan yang menerapkan konsep multikultural karena mengingat wilayah balun sangat erat dengan banyaknya agama yang berbeda sehingga tidak menutup kemungkinan berimbas pada para siswa yang multi agama.

\section{Nilai-nilai Multikultural yang Diintegrasikan dalam Pembelajaran PAI di SDN 1 Balun Turi Lamongan}

Dari hasil yang peneliti lakukan di SDN 1 Balun Turi Lamongan, ada enam nilai-nilai multikultural yang terintegrasikan dalam pembelajaran PAI di sekolah ini, antara lain:

\section{Nilai Inklusif (Terbuka)}

Nilai inklusif menjadi salah satu nilai yang diterapkan di sekolah ini, nilai inklusif adalah rasa keterbukaan antar sesama warga sekolah, salah satu nilai ini tercermin dari sikap para peserta didik SDN 1 Balun Turi Lamongan yang bisa saling terbuka meski mereka beda agama, ini diperkuat dengan pernyataan kepala sekolah:

"sikap inklusif di sekolah ini sangat diterapkan mbak, oleh sebab itu antar siswa bisa saling terbuka artinya bisa saling berteman dan bersahabat tanpa mentautkan perbedaan agama" 13

12 John W. Creswell, Qualitative Inquiry \& Research Design: Choosing among Five Approaches, 2nd ed (Thousand Oaks: Sage Publications, 2007); Moloeng Lexy J, Metodologi penelitian Kualitatif, 29th ed. (Bandung: Rosdakarya, 2011).

${ }^{13}$ Sutrisno, Wawancara, Kepala Sekolah SDN 1 Balun Turi Lamongan, April 5, 2019. 
Sikap inilah yang menjadi prinsip SDN 1 Balun Turi Lamongan sekaligus sebagai dasar politik kebebasan beragama.

\section{Nilai Kemanusiaan (Humanis)}

dilingkungan ini menjadi salah satu faktor terbentuknya sikap seorang manusia, SDN 1 balun Turi Lamongan ini menjadi SD yang menerapkan sikap nilai kemanusiaan karena SD ini memiliki keunikan yakni memiliki warga yang multikultural dengan warga yang berlatarbelakang beda agama, berdasarkan pengamatan peneliti, sekolah ini telah mencerminkan penerapan nilai kemanusiaan, hal ini diperkuat dengan pernyataan guru agama, yakni:

"Ketika peringatan hari besar Islam atau agama lain, anak-anak saling menghargai dan ikut andil dalam acara tersebut mbak."14

Pernyataan ini menunjukkan, kemanusiaan manusia pada dasarnya adalah pengakuan akan pluralitas, heterogenitas, dan keragaman manusia itu sendiri. Keragaman itu bisa berupa ideologi, agama, paradigma, suku bangsa, pola pikir, kebutuhan, tingkat ekonomi, dan sebagainya.

\section{Nilai Toleransi}

Tradisi sosio-kultur yang toleran sangat mempengaruhi tatanan toleransi beragama yang berbeda di SDN 1 Balun Turi lamongan ini. Hal ini juga diperkuat oleh pernyataan dari Guru Agama Islam SDN 1 Balun Lamongan sebagai berikut:

“Toleransi itu sangat penting mbak, agar bangsa ini tidak terpecah belah karena perbedaan agama. Jadi kami para guru disini terutama saya ketika merancang RPP dan Silabus itu ya sesuai dengan keadaan disini yang kebetulan siswa-siswi disini ada yang berbeda-beda agama, makanya ketika merancang itu kita masukkan nilai-nilai multikultural itu dalam setiap bab atau sub bab pembahasan, agar para murid kita itu saling mengerti dan memahami. Jadi semuanya dimulai dari kita dulu kemudian kita turun kelapangan untuk mengajarkannya. Bagi saya pendidikan multikultural itu penting apalagi ketika murid kita ada yang berbeda agama, kita kalau dikelas ya dituntut untuk bisa adil mbak dalam memberikan penjelasan tentang mata pelajaran tanpa membedabedakan" $" 15$.

Hal ini juga diperkuat oleh pernyataan dari Siswa SDN 1 Balun Lamongan sebagai berikut:

\footnotetext{
2019.

${ }^{14}$ Ummah Khoirul, Wawancara, Guru Pendidikan Agama islam SDN 1 Balun Turi Lamongan, April 5, ${ }^{15}$ Khoirul.
} 
"Ya penting kak, soalnya kita bisa mengetahui dan menghormati tementemen yang beda agama, disini kan ada tiga agama yang berbeda, islam, kristen dan hindu. Pak guru juga gak memandang agamanya apa kok". ${ }^{16}$

Proses pembelajaran sejatinya memperhatikan setiap individu masing-masing siswa sesuai dengan kapasitas dan kapabilitas para siswa dengan pembelajaran yang intens karena memang menumbuhkan semangat belajar siswa SD gampang-gampang susah. Sejatinya semua siswa mempunyai hak yang sama dalam menerima pelajaran.

\section{Nilai Tolong Menolong}

Nilai tolong-menolong menjadi suatu kebiasaan yang dilalukan di SDN 1 Balun Turi Lamongan ini, dengan nilai tolong-menolong ini warga sekolah dalam kehidupannya seharihari menjadi harmonis nan indah.

\section{Nilai Keadilan (Demokratis)}

Nilai keadilan atau demokratis ini dijunjung tinggi di sekolah ini, hal ini tercermin dari sikap guru yang tanpa membeda-bedakan siswa, sesuai dengan pernyataan kepala sekolah yakni:

"setiap rapat berlangsung mbak, tanpa lupa selalu saya ingatkan agar seluruh dewan guru dalam kegiatan belajar-mengajar baik di luar maupun di dalam kelas tidak membeda-bedakan siswa yang berlatarbelakang agama berbeda". ${ }^{17}$

Keadilan merupakan sebuah istilah yang menyeluruh dalam segala bentuk, baik keadilan budaya, politik, maupun sosial. Keadilan sendiri merupakan bentuk bahwa setiap insan mendapatkan apa yang ia butuhkan, bukan apa yang ia inginkan.

\section{Nilai Persamaan dan Persaudaraan (Ukhuwah)}

Nilai ukhuwah ini merupakan nilai dasar yang ditanamkan oleh para guru kepada para siswa, dengan pondasi yang kuat nilai ukhuwah ini maka semua nilai akan terbangun dengan baik, ini sesuai yang disampaikan oleh kepala sekolah SDN 1 Balun Turi Lamongan, yaitu:

"ada nilai dasar yang ditanamkan di sekolah ini mbak, yaitu nilai ukhuwah, dengan pondasi yang kuat maka kehidupan harmonis terjalin di sekolah ini"'.

\footnotetext{
${ }^{16}$ Danis A Ahmad, Wawancara, Siswa Kelas IV SDN 1 Balun Turi Lamongan, April 5, 2019.

${ }^{17}$ Sutrisno, Wawancara.

18 Sutrisno.
} 
Berdasarkan penelitian yang dilakukan oleh peneliti kehidupan yang terjalin di SDN 1 Balun Turi Lamongan mencerminkan kehidupan yang harmonis karena dalam kegiatan sehari - hari terjalin nilai ukbuwah. Hal ini juga dikuatkan oleh penuturan dari guru agama:

"Selama ini mbak, kita saling berkomitmen untuk selalu berjuang dalam memperjuangkan toleransi terhadap agama yang berbeda disini, tetapi hal itu tidak langsung bisa mbak, perlu waktu dan juga rancangan yang matang dan juga bantuan dari beberapa pihak terutama pihak guru, murid, dan juga wali murid yang selalu memberikan keyakinan anak mereka kepada kami"19.

\section{Pelaksanaan Integrasi Nilai-Nilai Multikultural dalam Pembelajaran PAI \\ Integrasi Nilai-nilai Multikultural dalam Pembelajaran PAI di Kelas}

Beberapa komponen yang perlu diperhatikan dalam pelaksanaan integrasi nilai-nilai multikultural dalam pembelajaran PAI di kelas, antara lain: 1) Tujuan pembelajaran, 2) Bahan pembelejaran, 3) Pelaksanaan Pembelajaran 4) Metode Pembelajaran dan 5) Evaluasi pembelajaran.

Evaluasi pendidikan multikultural minimal terdapat tiga bagian yang harus dilengkapi antara lainnya adalah Persepsi, Apresiasi dan juga tindakan peserta didik terhadap lingkungan agama yang berbeda, dari ini lah diharapkan peserta didik mampu mengukur keberhasilan dalam terwujudnya pembelajaran pendidikan agama Islam.

Pelaksanaan Integrasi Nilai-Nilai Multikultural dalam Pembelajaran PAI di

\section{Luar Kelas}

Integrasi yang dilakukan SDN 1 Balun Turi Lamongan tidak hanya melalui proses belajar mengajar di dalam kelas saja. Akan tetapi juga diaplikasikan pada kegiatan seharihari untuk melatih sikap siswa agar terbiasa melakukanya dalam kehidupan. Hal ini dilakukan oleh sekolah karena pendidikan multikultural pada dasarnya menekankan dari knowing menjadi doing. Oleh karena itu, pelaksanaan integrasi nilai-nilai multikultural di SDN 1 Balun Turi Lamongan dilakukan melalui kegiatan rutinan seperti:

\section{Upacara Bendera}

Upacara Bendera merupakan salah satu kegiatan yang diadakan di SDN 1 Balun Turi Lamongan, setiap hari senin sebelum kegiatan belajar dimulai. Salah satu media untuk menanamkan nilai-nilai multikultural dapat dilakukan melalui upacara bendera. Hal ini sesuai dengan pernyataan yang di sampaikan oleh kepala sekolah, yakni:

"Itu mbak, untuk menanamkan nilai-nilai multikultural diluar kelas, salah satunya adalah dengan kegiatan upaca bendera, dalam kegiatan ini ada

${ }^{19}$ Sujud, Wawancara Guru Agama Hindu SDN 1 Balun Turi Lamongan, April 5, 2019. 
sambutan dari Pembina upacara, biasanya dalam sambutan ini ada sepatadua kata yang disampaikan terkait dengan penerapan nilai-nilai multikultural di sekolah ini", ${ }^{20}$

Upacara bendera merupakan waktu yang tepat untuk menanamkan nilai- nilai multikultural pada siswa dan juga sebagai salah satu bentuk pembelajaran pendidikan agama Islam. Oleh karena itu, pembina upacara diharapkan dapat menyampaikan pentingnya sikap rukun, toleran dan saling menghormati terhadap sesama pada siswa, sehingga makna dari upacara dapat disampaikan tidak hanya sebagai sebuah kegiatan yang terbatas pada pembentukan kedisiplinan akan tetapi menjadi suatu pembentuk sikap kepribadian yang pluralis dan agamis bagi peserta didik SDN 1 Balun Turi Lamongan.

\section{Eksrtakurikuler}

Berdasarkan hasil penelitian yang dilakukan di SDN 1 Balun Turi Lamongan. Ekstrakurikuler merupakan bagian dari program pembinaan kesiswaan yang termasuk kelompok bidang peningkatan mutu pendidikan. Kegiatan ekstrakulikuler dirancang dalam rangka meningkatkan mutu pendidikan di sekolah untuk memperkuat penguasaan kompetensi dan memperkaya pengalaman belajar peserta didik melalui kegiatan di luar jam pelajaran. Hal ini sesuai dengan pernyataan yang disampaikan oleh kepala sekolah SDN 1 Balun Turi Lamongan.

"Untuk menerapkan nilai-nilai multikultural di sekolah ini, sekolah juga mengadakan ekstrakulikuler yang bisa diikuti oleh semua siswa mbak, selain para siswa bisa terampil juga memupuk rasa persaudaraan". ${ }^{21}$

Tujuan diadakannya kegiatan ekstrakulikuler di sekolah adalah untuk mengembangkan potensi, bakat, dan minat secara optimal. pembelajaran yang menekankan pada kebersamaan antar sesama. Di sekolah ini ada dua ekstrakulikuler yaitu pramuka dan baca tulis Al-qur'an.

Yang pertama ialah pramuka, kegiatan ini di SDN 1 Balun Turi Lamongan disisipkan permainan dan keterampilan. Selain itu, kegiatan ini juga sabagai salah satu bentuk pembelajaran pendidikan agama Islam yakni mendidik siswa untuk memiliki rasa tenggang rasa yang tinggi sebagai makhluk sosial. Selain pembentukan karakter yang dapat dilakukan melalui berbagai macam permainan, pramuka juga mengajarkan pada siswa untuk terlatih bersikap disiplin.

${ }^{20}$ Sutrisno, Wawancara.

${ }^{21}$ Sutrisno. 
Hal ini diwujudkan dengan mengajarkan siswa cara baris berbaris yang merupakan salah satu cara membiasakan siswa bersikap teratur. Melalui pramuka jugalah pentingnya arti ke-bhinekaan tunggal ika ditanamkan pada siswa. Sikap toleransi dan kerukunan serta sikap-sikap multikultural yang lain disisipkan disetiap pertemuan agar kelak setelah lulus siswa-siswi SDN 1 Balun Turi Lamongan menjadi masyarakat yang humanis dan bangga dengan Negara Indonesia.

Ke dua ialah baca tulis Al-qur'an, kegiatan ekstra ini juga merupakan salah satu bentuk pembelajaran pendidikan agama Islam, khusus ekstra ini hanya diikuti oleh para siswa yang beragama Islam saja, kegiatan ini dilakukan seminggu sekali di luar jam pelajaran, tempatnya di ruang kelas sekolah. Hal ini berdasarkan pernyataan oleh guru pendidikan agama Islam: "di sekolah ini ada ekstra baca tulis Al'quran mbak, untuk memperdalam ilmu agama bagi anak-anak". 22 Ekstra baca tulis Al qur'an ini memang hanya di peruntukkan untuk para siswa yang beragama Islam saja, karena dimaksudkan untuk mempertajam pengetahuan tentang baca tulis al qur'an siswa.

\section{Faktor Pendukung Dan Penghambat Integrasi Nilai - Nilai Multikultural dalam Pembelajaran PAI Di SDN 1 Balun Turi Lamongan}

Pelaksanaan integrasi nilai-nilai multikultural dalam pembelajaran Pendidikan agama Islam di SDN 1 Balun Turi Lamongan terdapat faktor pendukung dan faktor penghambat. Banyak faktor pendukung dalam proses integrasi ini baik dari secara internal maupun eksternal. Faktor pendukung yang bersifat internal adalah kurikulum pendidikan yang terpadu dan buku-buku pelajaran yang bermuatan konten multikultural sedangkan faktor eksternal adalah lingkungan yang kondusif dan agamis baik di dalam sekolah maupun di lingkungan luar sekolah. Hal ini sesuai dengan pernyataan kepala sekolah yakni:

"Banyak faktor pendukung integrasi yang ada di sekolah ini mbak, sehingga sekolah ini mencerminkan adanya pelaksanaan integrasi nilai multikultural, Alhamdulillah, dan saya rasa untuk faktor penghambatnya itu kurangnya media keberagaman di sekolah ini, kurangnya muatan konten multikultural dalam RPP dan komunikasi anak-anak dalam proses pembelajaran"

Sedangkan faktor penghambatnya adalah kurangnya media keberagaman, kurangnya pemahaman tentang isi buku pelajaran dikarenakan terbiasa interaksi menggunakan bahasa jawa, konten muatan multikultural dalam RPP masih kurang sehingga yang mendominasi adalah faktor lingkungan.

${ }^{22}$ Khoirul, Wawancara. 


\section{TEMUAN}

Dari ketiga fokus penelitian ini maka temuan penelitian akan di gambarkan sebagai berikut:

Gambar 1. Hasil Penelitian: integrasi nilai-nlai multikultural di Sekolah Dasar

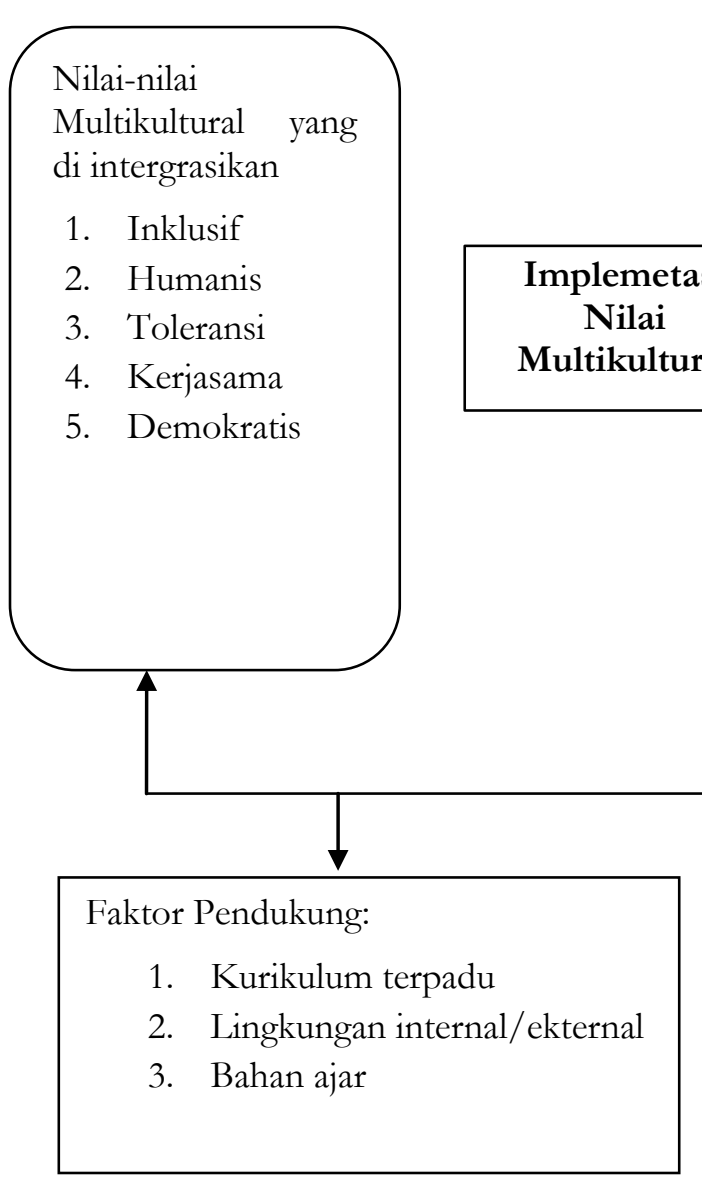

1. Dalam Pembelajaran (kontrol RPP, Sylabus)

2. Kegiatan Rutinan (Upacara bendera mingguan)

3. Ekstrakulikuler (Ke-pramukaan dan Baca Tulis Qur'an

\section{DISKUSI DATA}

Nilai-nilai Multikultural yang diintegrasikan ke dalam Pembelajaran PAI di SDN 1

\section{Balun Turi Lamongan}

\section{Nilai Inklusif (Terbuka)}

Firman Allah SWT:

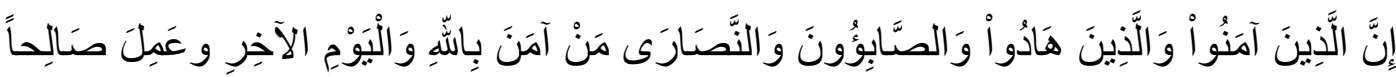

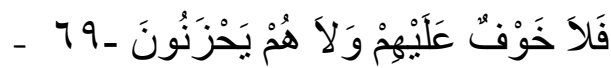

"Sesungguhnya orang-orang mukmin, orang-orang Yahudi, Shabiin dan orangorang Nasrani, siapa saja (diantara mereka) yang benar-benar saleh, maka tidak ada 
kekhawatiran terhadap mereka dan tidak (pula) mereka bersedih hati ${ }^{23}$,

Sikap inklusif ada karena $\mathrm{Al}$ qur'an mengajarkan paham religious plurality. Bagi orang Islam, dianut suatu keyakinan bahwa sampai hari ini pun di dunia ini akan terdapat keragaman agama ${ }^{24}$.

Peserta didik SDN 1 Balun Turi Lamongan didalam maupun diluar lingkungan sekolah diajarkan untuk bersifat terbuka dengan yang lain. Sikap inklusif ada karena Al qur'an mengajarkan paham religious plurality. Bagi orang Islam, dianut suatu keyakinan bahwa sampai hari ini pun di dunia ini akan terdapat keragaman agama ${ }^{25}$.

\section{Nilai Kemanusiaan (Humanis)}

Firman Allah SWT:

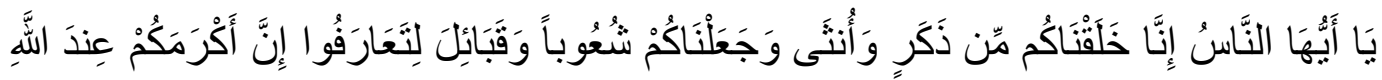

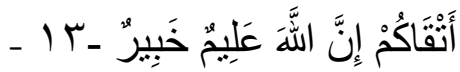

"Hai manusia, Sesungguhnya Kami menciptakan kamu dari seorang laki-laki dan seorang perempuan dan menjadikan kamu berbangsa - bangsa dan bersuku-suku supaya kamu saling kenal-mengenal. Sesungguhnya orang yang paling mulia diantara kamu disisi Allah ialah orang yang paling taqwa diantara kamu. Sesungguhnya Allah Maha mengetahui lagi Maha Mengenal"26

Berdasarkan hal tersebut, pendidikan (Islam) dinilai sebagai "sistem sosial" senantiasa merefleksikan filosofi komunitas pendukungnya hal ini dikutip oleh Mahmud Arif dalam Yaya Suryana. Dengan demikian, pendidikan dan pembelajaran yang bersifat aktif-positif serta berdasarkan minat dan kebutuhan siswa sangat penting untuk memperoleh kemajuan, baik dalam bidang intelektual emosi (EQ), afeksi, maupun keterampilan yang berguna untuk hidup praktis ${ }^{27}$.

Berdasarkan keterangan yang disampaikan oleh kepala sekolah SDN 1 Balun Turi Lamongan kepada peneliti bahwa untuk menjaga nilai humanisme di lingkungan sekolah salah satunya adalah setiap peserta didik diberi kebebasan yang sama untuk mengikuti kegiatan belajar mengajar yang berlangsung di sekolah termasuk bidang agama.

23 Al-Qur`an (Jakarta: Kementerian Agama RI, 2010), 5: 69.

24 Yaya Suryana, Pendidikan Multikulkultural: Suatu Upaya Penguatan Jati Diri Bangsa: Konsep-PrinsipImplementasi, Cet. I (Bandung: Pustaka Setia, 2015), 329.

25 Suryana, 329.

26 Al-Qur`an, 49: 13.

27 Suryana, Pendidikan Multikulkultural, 324. 


\section{Nilai Toleransi}

Firman Allah SWT

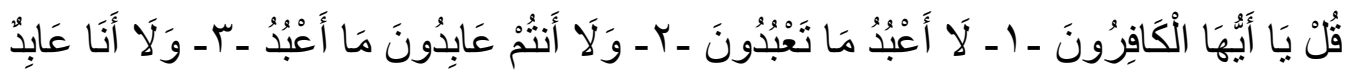

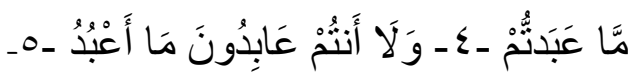

"Katakanlah: "Hai orang-orang kafir. Aku tidak akan menyembah apa yang kamu sembah. dan kamu bukan penyembah Tuhan yang aku sembah. dan aku tidak pernah menjadi penyembah apa yang kamu sembah, dan kamu tidak pernah (pula) menjadi penyembah Tuhan yang aku sembah" (Q.S. Al Kaafirun109:1-5) 28 $^{2}$

Namun perlu digarisbawahi di sini, toleransi dalam hal keagamaan bukan dimaknai sebagai sikap menerima ajaran agama- agama lain, seperti dalam hal kepercayaan. Melainkan perwujudan sikap keberagamaan pemeluk satu agama dalam pergaulan hidup dengan orang yang tidak seagama. Sebagai umat yang beragama, diharapkan dapat membangun sebuah tradisi wacana keagamaan yang menghargai keberadaan agama lain, dan bisa menghadirkan wacana agama yang toleransi dan transformatif. ${ }^{29}$

Pendidikan agama Islam di SDN 1 Balun Tuti Lamongan menampilkan ajaranajaran Islam yang toleran melalui kurikulum pendidikannya dengan tujuan menitikberatkan pada pemahaman dan upaya untuk bisa hidup dalam konteks berbeda agama dan budaya, baik secara individual maupun secara kelompok dan tidak terjebak pada primordialisme dan eksklusif kelompok agama dan budaya yang sempit.

\section{Nilai Tolong Menolong}

Firman Allah SW'T:

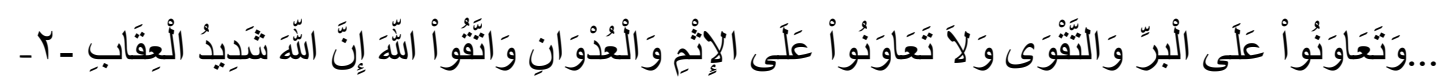

"Dan tolong-menolonglah kamu dalam (mengerjakan) kebajikan dan takwa, dan jangan tolong-menolong dalam berbuat dosa dan pelanggaran. Dan bertakwalah kamu kepada Allah, sesungguhnya Allah amat berat siksa-Nya" (QS. Al Maidah/5:2) ${ }^{30}$

Berdasarkan hasil observasi yang dilakukan oleh peneliti, nilai tolong-menolong sudah menjadi sebuah tradisi dilingkungan SDN 1 Balun Turi Lamongan, hal ini tercermin dari kegiatan sehari-hari di dalam dan di luar lingkungan sekolah yang

28 Al-Qur`an, 109: 1-5.

29 Nur Achmad and Nucholis Madjid, Pluralitas agama: kerukunan dalam keragaman (Kompas Media Nusantara, 2001), 39.

30 Al-Qur`an, 5: 2. 
harmonis antar sesama warga sekolah.

\section{Nilai Keadilan (Demokratis)}

Firman Allah SWT:

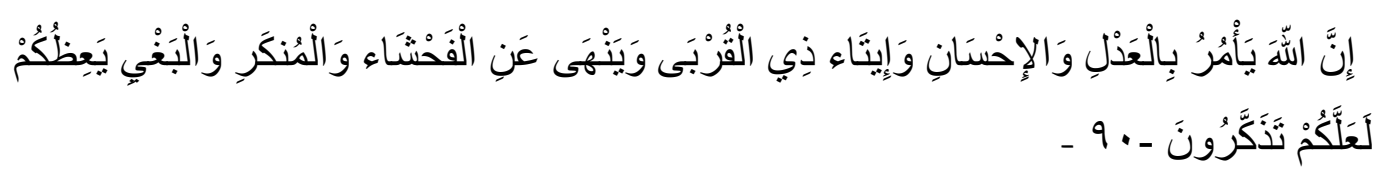

"Sesungguhnya Allah menyuruh (kamu) berlaku adil dan berbuat kebajikan, memberi kepada kaum kerabat, dan Allah melarang dari perbuatan keji, kemungkaran dan permusuhan. Dia memberi pengajaran kepadamu agar kamu dapat mengambil pelajaran" ${ }^{\prime 31}$

Demokratis dalam konteks pendidikan adalah sebagai pembebasan pendidik dan manusia dari struktur dan sistem perundang-undangan yang menempatkan manusia sebagai komponen. Demokrasi dalam pendidikan tidak saja melestarikan sistem nilai masa lalu tetapi juga bisa mempersoalkan dan merevisi sistem nilai tersebut. ${ }^{32}$

SDN 1 Balun Turi Lamongan dengan siswa yang multikultural telah mencerminkan kurikulum yang multikultural, sehingga hal ini berpengaruh dalam proses belajar mengajar di kelas, pendidik di tuntut untuk bersikap adil dan demokrasi.

a. Nilai Persamaan dan Persaudaraan (Ukbuwah)

Menurut Gillin dan Gillin dalam bukunya Soerjono Soekanto tentang kebersamaan, beliau menuliskan akan pentingnya proses asimilasi (asimilation), yang merupakan proses sosial dalam taraf lanjut yang ditandai dengan adanya usaha- usaha mengurangi perbedaan-perbedaan yang terdapat antara orang perorangan atau kelompok- kelompok manusia dan meliputi usaha-usaha untuk mempertinggi kesatuan tindak, sikap sikap dan proses-proses mental dengan memperhatikan kepentingankepentingan tujuan bersama. ${ }^{33}$

Di SDN 1 Balun Turi Lamongan ukhuwah sudah terjalin, bahkan bukan hanya dengan warga sekolah saja akan tetapi dengan masyarakat setempat, hal ini bisa penulis katakan berdasarkan hasil observasi yang dilakukan peneliti, salah satu contohnya adalah letak gedung sekolah ini berdekatan dengan tempat peribadatan ketiga agama yaitu Islam, Kristen dan Hindu akan tetapi selama ini tidak pernah terjadi keributan atau perpecahan akibat hal ini.

\footnotetext{
${ }^{31}$ Al-Qur`an, 16: 90.

${ }^{32}$ Ngainun Naim and Achmad Sauqi, Pendidikan Multikultural: Konsep Dan Aplikasi, Cet. 1 (Depok, Sleman, Jogjakarta: Ar-Ruzz Media : Didistribusikan oleh Ar-Ruzz Media Group, 2008), 61.

33 Soerjono Soekanto, Sosiologi, suatu pengantar (Remadja Karya CV, 2002), 80.
} 


\section{Integrasi Nilai - nilai Multikultural dalam Pembelajaran PAI di SDN 1 Balun Turi} Lamongan

\section{Pelaksanaan Integrasi Nilai-Nilai Multikultural dalam Pembelajaran PAI di Kelas}

Suatu proses belajar mengajar dapat berjalan efektif apabila seluruh komponen yang berpengaruh dalam proses belajar mengajar saling mendukung dalam rangka mencapai tujuan pembelajaran sebagai suatu sistem, tentu saja kegiatan belajar mengajar khususnya pendidikan agama Islam mendukung sejumlah komponen dan berpengaruh terhadap proses pembelajaran pendidikan agama Islam, hal ini meliputi tujuan, bahan pelajaran, kegiatan belajar mengajar, alat, metode, sumber belajar, evaluasi ${ }^{34}$.

\section{Pelaksanaan Integrasi Nilai-Nilai Multikultural dalam Pembelajaran PAI di}

\section{Luar Kelas}

\section{Upacara Bendera}

Kegiatan upacara bendera ini termasuk dalam kategori kurikulum sekolah, kurikulum yang multikultur mencerminkan keseimbangan antara pemahaman persamaan dan perbedaan budaya. Dalam kagiatan ini semua peserta didik harus ikut tanpa memandang latarbelakang ras dan kebudayaannya. Hal ini sesuai yang disampaikan oleh Yaya Suryana yaitu kurikulum multikultur harus mendukung prinsipprinsip pokok dalam memberantas pandangan klise tentang ras, budaya dan agama ${ }^{35}$.

\section{Ekstrakurikuler}

Tujuan diadakannya kegiatan ekstrakurikuler di sekolah adalah untuk mengembangkan potensi, bakat, dan minat secara optimal. pembelajaran yang menekankan pada kebersamaan antar sesama. Serta ada proses pendidikan didalamnya. Ada dua ekstrakulikuler yang dikembangkan di sekolah ekstrakulikuler, yang pertama adalah pramuka, kegiatan ini di SDN 1 Balun Turi Lamongan disisipkan permainan dan ketrampilan. Selain itu, kegiatan ini juga mendidik siswa untuk memiliki rasa tenggang rasa yang tinggi sebagai makhluk sosial. Selain pembentukan karakter yang dapat dilakukan melalui berbagai macam permainan, pramuka juga mengajarkan pada siswa untuk terlatih bersikap disiplin. Hal ini diwujudkan dengan mengajarkan siswa cara baris berbaris yang merupakan salah satu cara membiasakan siswa bersikap teratur. Melalui

${ }^{34}$ Djamarah Syaiful Bahri and Aswan Zain, Strategi Belajar Mengajar (Jakarta: Rineka Cipta, 2010), 45.

35 Suryana, Pendidikan Multikulkultural, 311. 
pramuka jugalah pentingnya arti ke-bhinekaan tunggal ika ditanamkan pada siswa. Sikap toleransi dan kerukunan serta sikap-sikap multikultural yang lain disisipkan disetiap pertemuan agar kelak setelah lulus siswa-siswi SDN 1 Balun Turi Lamongan menjadi masyarakat yang humanis dan bangga dengan Negara Indonesia.

Yang kedua adalah ekstra baca tulis Al qur'an, ekstra ini memang hanya di peruntukkan untuk para siswa yang beragama Islam saja, karena dimaksudkan untuk mempertajam pengetahuan tentang baca tulis al qur'an siswa. Dan ekstra ini juga menjadi salah satu aplikasi dari pembelajaran pendidikan agama Islam.

\section{Faktor Pendukung Dan Penghambat Integrasi Nilai - Nilai Multikultural Dalam Pembelajaran PAI Di SDN 1 Balun Turi Lamongan}

Pelaksanaan integrasi nilai-nilai multikultural dalam pembelajaran pendidikan agama Islam di SDN 1 Balun Turi Lamongan terdapat faktor pendukung dan faktor penghambat. Banyak faktor pendukung dalam proses integrasi ini baik dari pihak internal maupun eksternal. Faktor pendukung dari pihak internal adalah kurikulum pendidikan yang terpadu dan buku-buku pelajaran yang bermuatan konten multikultural sedangkan faktor eksternal adalah lingkungan yang kondusif dan agamis baik di dalam sekolah maupun di lingkungan luar sekolah.

Sedangkan faktor penghambatnya adalah kurangnya media keberagaman di lingkungan sekolah, kurangnya pemahaman tentang isi buku pelajaran dikarenakan terbiasa interaksi menggunakan bahasa jawa dan konten muatan multikultural dalam RPP masih kurang sehingga yang mendominasi adalah faktor lingkungan.

\section{KESIMPULAN}

Bentuk integrasi nilai-nilai multikultural dalam pembelajaran pendidikan agama Islam di SDN 1 Balun Turi Lamongan dapat dilihat dari rumusan visi, misi, tujuan sekolah dan model kurikulum, dimana kurikulum yang dikembangkan sesuai dengan kurikulum pembelajaran PAI yang berwawasan multikultural. Ada enam bentuk nilai-nilai multikultural yang terintegrasi dalam pembelajaran pendidikan agama Islam di SDN 1 Balun Turi Lamongan, ke enam bentuk nilai tersebut adalah nilai inklusif, nilai humanis, nilai toleransi, nilai tolong menolong, demokrasi dan ukhuwah. Pelaksanaan integrasi nilai-nilai multikultural dalam pembelajaran pendidikan agama Islam di SDN 1 Balun Turi Lamongan dilakukan dalam perencanaan pembelajaran, pelaksanaan pembelajaran, evaluasi pembelajaran. Dalam 
perencanaan, pelaksanaan dan evaluasi pembelajaran dilakukan di dalam dan di luar kelas. Di dalam kelas dengan mencantumkan nilai- nilai multikultural dalam silabus dan RPP. Dan di luar kelas dengan kegiatan ekstrakulikuler. Pelaksanaan integrasi nilai-nilai multikultural dalam pembelajaran pendidikan agama Islam di SDN 1 Balun Turi Lamongan terdapat faktor pendukung dan faktor penghambat. Banyak faktor pendukung dalam proses integrasi ini, ditinjau dari sisi internal maupun eksternal. Faktor pendukung dari sisi internal adalah kurikulum pendidikan yang terpadu dan buku-buku pelajaran yang bermuatan konten multikultural sedangkan faktor eksternal adalah lingkungan yang kondusif dan agamis di dalam sekolah maupun di lingkungan luar sekolah. Sedangkan faktor penghambatnya adalah kurangnya media keberagaman di lingkungan sekolah, kurangnya pemahaman tentang isi buku pelajaran dikarenakan terbiasa interaksi menggunakan bahasa jawa dan konten muatan multikultural dalam RPP masih kurang sehingga yang mendominasi adalah faktor lingkungan.

Rekomendasi: Dari hasil pengamatan yang dilakukan penulis, ada beberapa saran dan rekomendasi terkait dengan penelitian ini antara lain: Untuk peneliti selanjutnya agar dapat mengembangkan dari aspek lain. Misalnya tentang strategi atau metode tentang pengintegrasian nilai-nilai multikultural dalam pembelajaran pendidikan agama Islam yang lebih spesifik lagi. 


\section{REFERENSI}

Abdullah, Jihan. "Pendidikan islam multikultural di pesantren (studi kasus pada pondok modern ittihadul ummah gontor poso)." Istiqra 2, no. 1 (June 30, 2014): 95-123. https://doi.org/10.24239/istq.v2i1.103.95-123.

Achmad, Nur, and Nucholis Madjid. Pluralitas agama: kerukunan dalam keragaman. Kompas Media Nusantara, 2001.

Ahimsa-Putra, Heddy Shri. "Fenomenologi Agama: Pendekatan Fenomenologi Untuk Memahami Agama." Walisongo: Jurnal Penelitian Sosial Keagamaan 20, no. 2 (December 15, 2012): 271-304. https://doi.org/10.21580/ws.20.2.200.

Ahmad, Danis A. Wawancara, Siswa Kelas IV SDN 1 Balun Turi Lamongan, April 5, 2019.

Al-Qur`an. Jakarta: Kementerian Agama RI, 2010.

Aprilianto, Andika, and Muhammad Arif. "Pendidikan Islam Dan Tantangan Multikultural: Tinjauan Filosofis.” Ną̧runa: Jurnal Pendidikan Islam 2, no. 2 (August 11, 2019): 279_ 89. https://doi.org/10.31538/nzh.v2i2.339.

Asrori, Achmad. "Contemporary Religious Education Model on the Challenge of Indonesian Multiculturalism.” JOURNAL OF INDONESLAN ISLAM 10, no. 2 (December 1, 2016): 261-84. https://doi.org/10.15642/JIIS.2016.10.2.261-284.

Banks, James A., ed. The Routledge International Companion to Multicultural Education. Routledge International Handbook Series. New York; London: Routledge, Taylor \& Francis Group, 2009.

Creswell, John W. Qualitative Inquiry \& Research Design: Choosing among Five Approaches. 2nd ed. Thousand Oaks: Sage Publications, 2007.

Engkus, Kuswarno. Metodelogi Penelitian Komunikasi, Fenomenologi, Konsepsi dan Pedoman. Bandung: Widya Padjadjaran, 2009.

Farid, Muhammad. Fenomenologi Dalam Penelitian Ilmu Sosial. Rawamangun, Jakarta: Kencana, 2018.

Hasbiansyah, O. "Pendekatan Fenomenologi: Pengantar Praktik Penelitian dalam Ilmu Sosial dan Komunikasi." MediaTor (Jurnal Komunikasi) 9, no. 1 (June 10, 2008): 163-80. https://doi.org/10.29313/mediator.v9i1.1146.

Ismail, Faisal. Dinamika kerukunan antarumat beragama: konflik, rekonsiliasi, dan barmoni. Cetakan pertama. Bandung: PT Remaja Rosdakarya, 2014. 
Ismail, Ismail. "Nilai-Nilai Karakter Dalam Pendidikan Agama Islam Berbasis Multikultural." TADRIS: Jurnal Pendidikan Islam 8, no. 2 (2014): 215-234.

Khoirul, Ummah. Wawancara, Guru Pendidikan Agama islam SDN 1 Balun Turi Lamongan, April 5, 2019.

Lexy J, Moloeng. Metodologi penelitian Kualitatif. 29th ed. Bandung: Rosdakarya, 2011.

Ma`arif, Muhammad Anas. "Internalisasi Nilai Multikulutural Dalam Mengembangkan Sikap Toleransi ( Studi Di Di Pesantren Mahasiswa Universitas Islam Malang).” Naz̧hruna: Jurnal Pendidikan Islam 2, no. 1 (March 24, 2019). https://doi.org/10.31538/nzh.v2i1.179.

—. "Pendidikan Multikultural Sebagai Pembentukan Karakter Peserta Didik." Ta'lim: Jurnal Studi Pendidikan Islam 2, no. 2 (July 15, 2019): 136-52. https://doi.org/10.29062/ta'lim.v2i2.1413.

Malla, Hamlan Andi Baso. "Pembelajaran Pendidikan Agama Islam Berbasis Multikultural Humanistik Dalam Membentuk Budaya Toleransi Peserta Didik Di SMA Negeri Model Madani Palu, Sulawesi Tengah.” INFERENSI: Jurnal Penelitian Sosial Keagamaan 11, no. 1 (June 1, 2017): 163-86. https://doi.org/10.18326/infsl3.v11i1.163-186.

M.Pd, Dr Drs I. Wayan Suwendra, S. Pd. Metodologi Penelitian Kualitatif dalam Ilmu Sosial, Pendidikan, Kebudayaan dan Keagamaan. Nilacakra, 2018.

Munawar, Said Aqil Husin Al, Hasan M. Noer, and Musyafaullah. Hukum Islam dan pluralitas sosial. Penamadani, 2004.

Mursyid, Mursyid. "Internalisasi Nilai Keberagaman Agama Dan Paham Keislaman Di Pondok Pesantren: A Sociological Approaches." Jurnal Kependidikan Islam 5, no. 2 (August 1, 2015): 125-48.

Naim, Ngainun, and Achmad Sauqi. Pendidikan Multikultural: Konsep Dan Aplikasi. Cet. 1. Depok, Sleman, Jogjakarta: Ar-Ruzz Media: Didistribusikan oleh Ar-Ruzz Media Group, 2008.

Nindito, Stefanus. "Fenomenologi Alfred Schutz: Studi Tentang Konstruksi Makna Dan Realitas Dalam Ilmu Sosial.” Jurnal Ilmu Komunikasi 2, no. 1 (2013).

Nugroho, Muhammad Aji. "Pendidikan Islam Berwawasan Multikultural; Sebuah Upaya Membangun Pemahaman Keberagamaan Inklusif Pada Umat Muslim.” MUDARRIS A: Jurnal Kajian Pendidikan Islam 8, no. 1 (September 10, 2016): 31-60. https://doi.org/10.18326/mdr.v8i1.31-60. 
Integrasi Nilai Multikultural Dalam Pembelajaran

Nugroho, Puspo. "Internalization of Tolerance Values in Islamic Education.” Nadwa 12, no. 2 (January 7, 2019): 197-228. https://doi.org/10.21580/nw.2018.12.2.2397.

Raihani. Pendidikan Islam Dalam Masyarakat Multikultural. Cet. 1. Yogyakarta: Pustaka Pelajar, 2016.

Soekanto, Soerjono. Sosiologi, suatu pengantar. Remadja Karya CV, 2002.

Sudarsyah, Asep. "Kerangka Analisis Data Fenomenologi (contoh Analisis Teks Sebuah Catatan Harian)." Jurnal Penelitian Pendidikan 13, no. 1 (August 23, 2016). http://ejournal.upi.edu/index.php/JER/article/view/3475.

Suharsimi, Arikunto. Prosedur Penelitian, Suatu Pendekatan Teori dan Praktek. 14th ed. Jakarta: Rineka Cipta, 2010.

Sujud. Wawancara Guru Agama Hindu SDN 1 Balun Turi Lamongan, April 5, 2019.

Suryana, Yaya. Pendidikan Multikulkultural: Suatu Upaya Penguatan Jati Diri Bangsa: Konsep-PrinsipImplementasi. Cet. I. Bandung: Pustaka Setia, 2015.

Sutrisno. Wawancara, Kepala Sekolah SDN 1 Balun Turi Lamongan, April 5, 2019.

Syaiful Bahri, Djamarah, and Aswan Zain. Strategi Belajar Mengajar. Jakarta: Rineka Cipta, 2010.

Zainiyati, Husniyatus Salamah. "Pendidikan Multikultural: Upaya Membangun Keberagamaan Inklusif Di Sekolah.” Islamica: Jurnal Studi Keislaman 1, no. 02 (2007): 135-145. 